\title{
HELMINTH INFECTION OF CHILDREN IN NGEMPLAK SENENG VILLAGE, KLATEN
}

\author{
Fitri Nadifah, Desto Arisandi, Nurlaili Farida Muhajir \\ ${ }^{1}$ Program Studi D3 Analis Kesehatan STIKES Guna Bangsa Yogyakarta \\ Jl.Ringroad Utara Depok Sleman Yogyakarta, telp: (0274)4477701 \\ E-mail: fitri.nadifah@gmail.com
}

\begin{abstract}
Helminth infection remains one of health problems of Indonesian people for years. The tropical condition of Indonesian climates with high level humidity has believed to be the one of factors that increase the number of this infection cases. Based of many studies, the number of helminth infections is related to the poor of hygiene and sanitation. This study is conducted to know the percentages of helminth infections among 0-14 years old children in Dusun Ngemplak, Desa Ngemplak Seneng, Klaten and also their personal hygiene with questionaire instruments. To know helminth infection in subjects, we examine faeces sample with simple method and $1 \%$ eosin dye. As the results of examination, we found Trichuris trichiura egg in three samples. This might related to the poor of their hygienic behaviors. Some of the behavior such as wash hand before eating and after defecation, use sandal or shoes when playing, consume helminthic drug for last 6 months, and defecate in toilet has shown percentage under $70 \%$. Other behaviors such as cutting and cleaning nails and use a spoon when eating has shown percentage above $70 \%$.
\end{abstract}

Keywords: helminth infections, hygienic behavior

\section{PENDAHULUAN}

Infeksi kecacingan merupakan salah satu masalah kesehatan masyarakat Indonesia, terutama di daerah pedesaan. Penyakit kecacingan ini dapat mengakibatkan menurunnya kondisi kesehatan, gizi, kecerdasan dan produktivitas penderitanya karena kehilangan karbohidrat, protein dan darah sehingga menurunkan kualitas sumber daya manusia (Kemenkes RI, 2006).

Kecacingan merupakan penyakit yang bersifat kronis, tidak mematikan tetapi mengganggu kesehatan tubuh manusia dan berakibat menurunkan kondisi gizi dan kesehatan masyarakat. Kecacingan umumnya disebabkan oleh infeksi cacing nematoda usus spesies Ascaris lumbricoides, Trichuris trichiura, Hookworm, dan Oxyuris vermicularis (Zulkoni, 2010). Nematoda usus ini merupakan penyebab kecacingan yang sering dijumpai pada masyarakat Indonesia khususnya pada usia anakanak (Soedarta, 2008). Penyakit kecacingan dapat terjadi karena minimnya pengetahuan masyarakat tentang higin sanitasi dan kurang terjaganya kebersihan diri dan lingkungan.

Penularan penyakit cacing dapat melalui berbagai cara. Telur cacing dapat masuk dan tinggal di dalam tubuh manusia. Telur cacing masuk ke dalam tubuh manusia melalui makanan, minuman dan mainanan dengan perantara tangan atau debu yang tercemar telur cacing. Setelah masuk ke dalam usus manusia, cacing akan berkembang kemudian membentuk koloni dan menyerap sari-sari makanan (Irianto, 2009).

Golongan cacing soil transmitted helminths (STH) adalah nematoda usus yang ditularkan melalui tanah dan tersebar luas diseluruh dunia, baik daerah yang 
tropis maupun sub tropis. Spesies STH yang sering menginfeksi manusia yaitu Ascaris lumbricoides, Trichuris trichiura, Necator americanus dan Ancylostoma duodenale (WHO, 2012).

Desa Ngemplak Seneng adalah salah satu desa dari Kecamatan Manisrenggo, Kabupaten Klaten, Provinsi Jawa Tengah. Mayoritas masyarakat desa ini bekerja dengan bertani karena struktur tanah yang cocok untuk pertanian. Namun menurut survei yang telah dilakukan, warga Desa Ngemplak Seneng masih belum memiliki pengetahuan tentang higin sanitasi yang memadai. Warga masih banyak yang buang air besar tidak di WC dan sering tidak menggunakan alas kaki. Selain itu, anak-anak dari warga desa ini juga banyak yang memiliki kebiasaan bermain di tanah, tidak mencuci tangan sebelum atau setelah makan, dan kurang terjaganya kebersihan diri.

Menurut Kemenkes RI (2006), usia sekolah dasar merupakan usia tertinggi penderita kecacingan di Indonesia. Jika tidak segera diatasi, maka kecacingan dapat menyebabkan menurunnya konsentrasi belajar dan terutama kualitas kesehatan siswa.

Infeksi kecacingan bisa menyebabkan morbiditas yang dapat menyerang semua golongan terutama golongan penduduk yang kurang mampu sehingga beresiko terinfeksi oleh cacing. Infeksi kecacingan banyak terjadi pada anak usia anak sekolah dan berpengaruh negatif terhadap pertumbuhan dan perkembangan mereka (Yulianto, 2007). Hasil penelitian yang telah dilakukan oleh Wibowo (2008) pada siswa SDN 03 Pringapus Kabupaten Semarang diperoleh hasil bahwa $11,3 \%$ siswa positif terinfeksi STH dengan jenis cacing Ascaris lumbricoides 16,7\%, cacing tambang $33,3 \%$, dan infeksi ganda (Ascaris lumbicoides dan Trichuris trichiura) $50 \%$.

Penelitian ini dilakukan untuk mengetahui persentase infeksi kecacingan dan perilaku personal higin pada anak di Dusun Ngemplak, Desa Ngemplak Seneng, Kabupaten Klaten. Hasil dari kegiatan ini diharapkan dapat memberikan gambaran kepada pemerintah setempat tentang kondisi sanitasi lingkungan dan pengetahuan masyarakat tentang higin sanitasi, serta langkah-langkah untuk menjaga atau meningkatkan taraf kesehatan warga daerah ini.

\section{METODE PELAKSANAAN}

Kegiatan ini dilakukan pada bulan Januari 2015 di Dusun Ngemplak, Desa Ngemplak Seneng, Kabupaten Klaten, Jawa Tengah. Penelitian diawali dengan observasi dan survei lapangan berupa pendataan kondisi lingkungan, fasilitas kesehatan, jumlah KK dan anak yang berusia 0-14 tahun. Pendataan dilakukan di kantor desa Ngemplak Seneng dan melalui data yang dimiliki Kepala Dusun Ngemplak.

Setelah dilakukan observasi dan survei, kemudian dilakukan pengarahan kepada orang tua tentang maksud dan tujuan penelitian, proses pengambilan sampel dan pemberian kuesioner penelitian. Pengarahan ini disertai dengan pemberian wadah sampel feses yang telah berisi formalin dan kuesioner penelitian.

Sampel feses yang diterima kemudian diperiksa di Laboratorium Klinik STIKES Guna Bangsa. Pemeriksaan keberadaan telur cacing dalam feses dilakukan dengan metode langsung dengan pewarnaan eosin 1\%. Untuk mengetahui perilaku dan tingkat pengetahuan responden tentang personal higin, maka hasil pengisian kuesioner yang diperoleh kemudian diolah dan disajikan secara deskriptif.

\section{HASIL DAN PEMBAHASAN}

Dari hasil observasi dan survei lapangan, dapat diketahui masih terdapat 9 rumah di Desa Ngemplak Seneng yang masih belum memiliki fasilitas mandi, cuci dan kakus (MCK). Hal ini diperparah dengan tidak adanya fasilitas MCK umum. Warga yang tidak memiliki MCK di rumah kemudian buang air di sungai atau jamban cemplung di sekitar rumah. Selain itu kondisi sanitasi lingkungan di sekitar rumah warga juga belum baik dengan banyaknya genangan-genangan air kotor yang terdapat di sekitar rumah, terdapat kandang hewan ternak yang berdampingan dengan rumah warga. 
Kondisi-kondisi ini menunjukkan bahwa warga masih belum menyadari tentang pentingnya menjaga kebersihan diri dan lingkungan. Rendahnya kesadaran warrga ini dapat menjadi faktor yang memicu infeksi kecacingan. Persebaran salah satu golongan cacing, yaitu soil transmitted helminths adalah lewat tanah sehingga kondisi sanitasi lingkungan yang tidak baik dapat mengakibatkan resiko infeksi cacing ini.

Desa Ngemplak Seneng juga masih minim fasilitas kesehatan dengan tidak adanya Puskesmas dan Praktek Dokter. Desa ini baru menyediakan satu pondok bersalin desa (Polindes). Minimnya fasilitas dan akses kesehatan ini dapat menjadi faktor penyebab rendahnya pengetahuan warga tentang higin sanitasi. Warga desa pada umumnya kurang menyadari kesehatan. Hal tersebut dibuktikan dengan kurangnya partisipasi masyarakat dalam kegiatan pemeriksaan yang telah dilakukan, walaupun telah diberikan pengetahuan tentang bahaya kecacingan.

Dari hasil observasi, dapat diketahui bahwa subjek penelitian, yaitu anak berusia 0-14 tahun berjumlah 23 orang. Dari jumlah ini, 15 orang berjenis kelamin laki-laki sedangkan sisanya berjenis kelamin perempuan. Jumlah anak yang berusia 6-12 tahun adalah yang paling banyak, yaitu 12 orang (Gambar 1).

\section{Jenis kelamin}

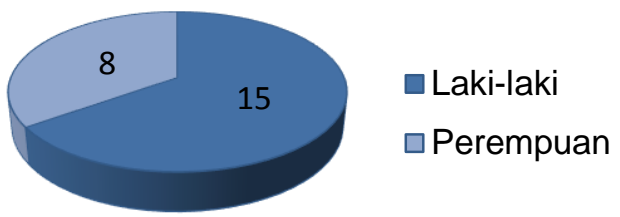

\section{Rentang umur}

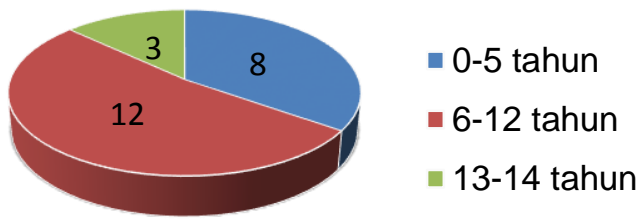

Gambar 1. Persentase jenis kelamin dan rentang umur anak yang menjadi subjek penelitian.

Data mengenai perilaku personal higin yang ingin diketahui dari kuesioner meliputi 7 kebiasaan, yaitu mencuci tangan sebelum makan, mencuci tangan dengan sabun sesudah buang air besar, menggunakan alas kaki saat bermain, memotong kuku yang panjang dan membersihkan kuku yang kotor, menggunakan sendok saat makan, minum

Tabel 1. Perilaku personal higin anak dari hasil pengisian kuesioner

\begin{tabular}{|c|c|c|c|c|}
\hline No & Perilaku & Jawaban & Jumlah & Kategori \\
\hline 1 & $\begin{array}{l}\text { Mencuci tangan } \\
\text { sebelum makan }\end{array}$ & $\begin{array}{l}\text { Ya } \\
\text { Tidak }\end{array}$ & $\begin{array}{l}8(50 \%) \\
8(50 \%)\end{array}$ & Rendah \\
\hline 2 & $\begin{array}{l}\text { Mencuci tangan } \\
\text { dengan sabun sesudah } \\
\text { buang air besar }\end{array}$ & $\begin{array}{l}\text { Ya } \\
\text { Tidak }\end{array}$ & $\begin{array}{c}2(12,5 \%) \\
14(87,5 \%)\end{array}$ & Rendah \\
\hline 3 & $\begin{array}{l}\text { Menggunakan alas kaki } \\
\text { saat bermain }\end{array}$ & $\begin{array}{l}\text { Ya } \\
\text { Tidak }\end{array}$ & $\begin{array}{l}9(56,25 \%) \\
7(43,75 \%)\end{array}$ & Rendah \\
\hline 4 & $\begin{array}{l}\text { Memotong kuku yang } \\
\text { panjang dan } \\
\text { membersihkan kuku } \\
\text { yang kotor }\end{array}$ & $\begin{array}{l}\text { Ya } \\
\text { Tidak }\end{array}$ & $\begin{array}{l}13(81,25 \%) \\
3(18,75 \%)\end{array}$ & Tinggi \\
\hline 5 & $\begin{array}{l}\text { Menggunakan sendok } \\
\text { saat makan }\end{array}$ & $\begin{array}{l}\text { Ya } \\
\text { Tidak }\end{array}$ & $\begin{array}{c}12(75 \%) \\
4(25 \%)\end{array}$ & Tinggi \\
\hline 6 & $\begin{array}{l}\text { Minum obat cacing } 6 \\
\text { bulan terakhir }\end{array}$ & $\begin{array}{l}\text { Ya } \\
\text { Tidak }\end{array}$ & $\begin{array}{c}0(0 \%) \\
16(100 \%)\end{array}$ & Rendah \\
\hline 7 & Buang air besar di WC & $\begin{array}{l}\text { Ya } \\
\text { Tidak }\end{array}$ & $\begin{array}{c}10(62,5 \%) \\
6(37,5)\end{array}$ & Rendah \\
\hline
\end{tabular}


obat cacing 6 bulan terakhir dan buang air besar di WC. Dalam tahap pengisian kuesioner ini, 16 dari 23 orang mengumpulkan kembali kuesioner yang sebelumnya telah diberikan. Perilaku dengan persentase tinggi adalah apabila persentasenya minimal $70 \%$ (12 orang) dari total responden.

Dari ketujuh perilaku, hanya dua diantaranya yang persentasenya tinggi, yaitu memotong dan membersihkan kuku yang kotor dan menggunakan sendok saat makan (Tabel 1). Responden masih menyadari pentingnya melakukan perilaku ini kemungkinan karena mendapatkan bimbingan dari orang tua di rumah dan guru di sekolah. Kemungkinan responden sudah mengetahui apa yang terjadi jika membiarkan kuku panjang dan kotor terhadap kesehatan mereka.

Hal yang perlu menjadi perhatian adalah tidak ada satu respondenpun yang pernah minum obat cacing selama enam bulan terakhir. Hal ini menunjukkan bahwa orang tua masih belum menyadari tentang perlunya minum obat cacing bagi anak untuk pencegahan kecacingan. Perilaku lain yang cukup rendah persentasenya adalah mencuci tangan dengan sabun setelah buang air besar (BAB), menggunakan alas kaki saat bermain dan buang air besar di WC. Jika tidak mencuci tangan setelah $\mathrm{BAB}$, maka sangat memungkinkan transmisi infeksi telur cacing dari feses yang kemudian menempel ke jari atau masuk ke sela-sela kuku.

Perilaku dan pengetahuan anak tentang kebersihan personal sangat ditentukan oleh pendampingan dari orang tua dan pengaruh lingkungan sekitar. Orang tua berhak untuk mendapatkan informasi tentang pentingnya menjaga personal higin dan sanitasi lingkungan melalui penyuluhan atau lewat akses kesehatan. Dengan demikian, pengetahuan ini kemudian diberikan dari orang tua kepada anak untuk lebih meningkatkan kesadaran menjaga personal higin. Informasi yang benar dan diperoleh anak sejak awal akan diterapkan anak dalam kegiatan sehari-hari dalam menjaga kebersihan diri dan lingkungan. Anak akan dapat mengetahui tentang ancaman infeksi berbagai penyakit jika tidak bisa menjaga kebersihan diri dan lingkungan sekitarnya.

Dari 16 orang responden yang bersedia mengisi kuesioner, hanya 12 orang diantaranya yang bersedia menyerahkan sampel feses untuk diperiksa. Sedikitnya jumlah sampel disebabkan karena responden masih takut untuk memberikan sampel feses.

Dari hasil pemeriksaan, ditemukan telur cacing Trichuris trichiura pada tiga sampel feses (Gambar 2). Telur cacing ini ditemukan pada 1 sampel feses responden umur 0-5 tahun dan 2 sampel feses responden umur 6-12 tahun. Telur cacing Trichuris trichiura mudah dikenali dari bentuknya yang khas, berbentuk seperti tempayan dengan ujung menonjol, berdinding tebal dan berisi larva (Gandahusada, 2000). Menurut Supali dan Margono (2008), cacing ini tersebar di seluruh kolon dan rektum dengan penderita terutama anak-anak dengan menunjukkan gejala diare yang sering diselingi sindrom disentri, anemia, berat badan menurun, dan juga sering disertai prolapsus rektum.

Angka kejadian infeksi kecacingan yang tinggi di Indonesia tidak terlepas dari keadaan Indonesia yang beriklim tropis dengan kelembaban udara yang tinggi serta tanah yang subur. Infeksi kecacingan tersebar luas, baik di pedesaan maupun di perkotaan. Infeksi kecacingan ini berhubungan erat dengan perilaku hidup sehat dan higin sanitasi lingkungan (Yulianto, 2007). Dari hasil penelitian ini, dapat diketahui bahwa infeksi kecacingan masih terjadi di antara warga, terutama anak-anak di Dusun Ngemplak, Desa Ngemplak Seneng. Hal ini disebabkan karena tingkat pengetahuan personal higin warga yang masih rendah, kondisi sanitasi lingkungan yang buruk, dan fasilitas kesehatan yang terbatas. Menurut Irianto (2009) pencegahan infeksi kecacingan dapat dilakukan dengan cara menjaga kebersihan diri dan lingkungan, buang air besar di WC, mencuci tangan dengan sabun sebelum makan dan setelah buang air besar, mencuci bersih sayur-sayuran atau memasak sebelum dimakan, pendidikan terhadap masyarakat terutama 
anak-anak tentang higin dan sanitasi dan minum obat cacing 6 bulan sekali.

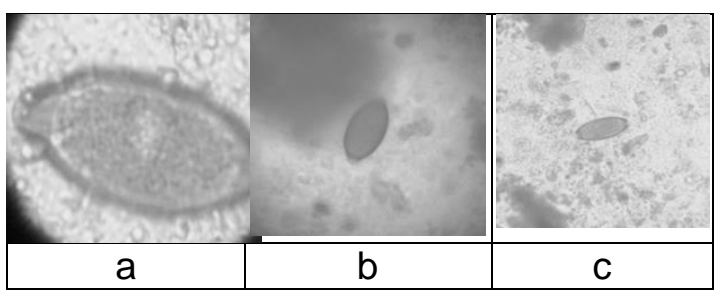

Gambar 2. Hasil Pemeriksaan

\section{KESIMPULAN DAN SARAN}

Terjadinya infeksi kecacingan pada anak menunjukkan bahwa orang tua masih belum memberikan pendidikan kesehatan yang memadai kepada anak. Kesadaran orang tua dan warga tentang higin sanitasi individu maupun lingkungan masih rendah. Hal ini dapat disebabkan karena faktor ekonomi dan masih kurangnya akses warga terhadap fasilitas kesehatan. Kami memberikan saran kepada pemerintah setempat untuk meningkatkan taraf kesehatan warga dengan langkah-langkah seperti meningkatkan akses warga terhadap fasilitas kesehatan, memperbaiki sanitasi lingkungan, memberikan penyuluhan tentang infeksi kecacingan dan mendirikan fasilitas WC umum. Kegiatan penyuluhan sangat diperlukan, baik terhadap warga maupun anak-anak sekolah. Jika warga telah memahami pentingnya menjaga kebersihan diri dan lingkungan, maka terjadinya

\section{UCAPAN TERIMA KASIH}

Kami mengucapkan terima kasih kepada LPPM STIKES Guna Bangsa Yogyakarta, Pemerintah Daerah Kabupaten Klaten dan Kepala Desa Ngemplak Seneng yang telah memberikan ijin untuk melakukan penelitian ini.

\section{DAFTAR PUSTAKA}

Gandahusada, S. 2000. Parasitologi Kedokteran. Fakultas Kedokteran UI. Jakarta

Irianto, K. 2009. Parasitologi. Yrama Widya. Bandung
Kemenkes RI. 2006. Pengendalian Cacingan. www.depkes.co.id. Diakses pada tanggal 20 Mei 2014. Yogyakarta

Onggowaluyo, J.S. 2002. Parasitologi Medik 1. Penerbit Buku Kedokteran EGC. Jakarta.

Soedarta. 2008. Parasitologi Klinik. Airlangga University Press. Surabaya.

Supali, T dan Margono, S.S. 2008. Parasitologi Kedokteran. FKUI. Jakarta

Wibowo, J.R. 2008. Hubungan antara Infeksi Soil Transmitted Helminth dengan Prestasi Belajar Anak Sekolah Dasar 03 Pringapus Kabupaten Semarang Jawa Tengah. Skripsi. Fakultas Kedokteran Universitas Diponegoro Semarang

Yulianto, D.I. 2009. Kejadian Kecacingan Soil Transmitted Helminth Berdasarkan Perilaku hidup sehat pada Pekerja Genteng di Desa Ngemblang Kulon Kecematan Jati Kudus. KTI. Jurusan Analis kesehatan Universitas Muhamaddiyah Semarang.

World Health Organization. 2012. WHO.2012. Soil transmitted helminth infection. Diakses dari http://www.who.int/mediacentre.com Zulkoni, A. 2010. Parasitologi. Penerbit Nuha Medika. Yogyakarta 